Review Paper

Doi: http://dx.doi.org/10.1590/1809-4430-Eng.Agric.v42n1e20210185/2022

\title{
FERTILIZER RECOMMENDATION METHODS FOR PRECISION AGRICULTURE - A SYSTEMATIC LITERATURE STUDY
}

\author{
Humberto M. Beneduzzi ${ }^{1}$, Eduardo G. de Souza ${ }^{2}$, Wendel K. O. Moreira ${ }^{2}$, \\ Ricardo Sobjak ${ }^{3}$, Claudio L. Bazzi ${ }^{3}$, Marlon Rodrigues ${ }^{2 *}$ \\ ${ }^{2 *}$ Corresponding author. Western Paraná State University / Cascavel - PR, Brazil. \\ E-mail: marlon.rodrig@hotmail.com | ORCID ID: https:/orcid.org/0000-0001-7661-9166
}

\section{KEYWORDS \\ fertilizing, variable rate application, site- specific management, systematic literature review.}

\begin{abstract}
Spatial variability management of soil chemical attributes is one of the approaches to be employed in the face of the constant challenge of increasing agricultural yield to meet world demand. In this sense, precision agriculture has as one of its tools the application of inputs at varying rates, which seeks to determine the ideal amount of fertilizer at each point of the crop, contrary to the conventional recommendation approach based on average values. In this context, this work studied the fertilizer recommendation methods used in site-specific nutrient management and the calculation methodologies for N, P, and $\mathrm{K}$ recommendations. For this purpose, a systematic literature study (SLS), consisting of systematic literature mapping, snowballing, and systematic literature review was performed. The analyzed studies were grouped into five domains (precision agriculture, soil fertility, site-specific nutrient application, fertilizer recommendation methods, and recommendation software for site-specific nutrient application). As a result, the SLS identified 12 methods for recommending $\mathrm{N}$, nine for recommending $\mathrm{P}$, and six for recommending $\mathrm{K}$, in addition to five computer programs for precision agriculture that perform fertilizer recommendations at varying rates.
\end{abstract}

\section{INTRODUCTION}

Agriculture in Brazil and the world has to face an increase in world demand for food, as the world population will reach $8.5,9.7$, and 11.2 billion people in 2030, 2050, and 2100 , respectively, according to projections by the United Nations (ONU, 2021). Therefore, the challenge will be to produce more with higher profitability and competitiveness, but sustainably, so that current and future human needs for food and environmental quality are guaranteed, and the natural resources remain preserved (Schnug et al., 1998).

Spatial variability management of soil chemical attributes is one of the possibilities of precision agriculture (PA) to increase yield. However, this management is complex because the effects of some nutrients, such as phosphorus $(\mathrm{P})$, are transferred from year to year, and nutrient transport rates depend on local conditions (Lambert et al., 2007). These authors found that $P$ transport rates were heterogeneous due to local topographic and chemical variations in the soil. The feasible of this management requires knowledge about the response of crops to applied inputs and the site-specific dynamics of nutrient transport (Lambert et al., 2007), as well as the spatial dependence of yield in the field (Bullock \& Lowenberg-DeBoer, 2007; Kahabka et al., 2004), providing increased efficiency of the production system and satisfying the economic and ecological demands of farmers (Beckie et al., 1997; Haneklaus \& Schnug, 2000; Tola et al., 2008; Waring \& Schlesinger, 1985).

Robust strategies for site-specific nutrient management must be based on a quantitative understanding of the consequent relationships between nutrient production

\footnotetext{
${ }^{1}$ Federal Institute of Paraná / Foz do Iguaçu - PR, Brazil.

${ }^{2}$ Western Paraná State University / Cascavel - PR, Brazil.

${ }^{3}$ Federal Technological University of Paraná / Medianeira - PR, Brazil.

Area Editor: Fabio Henrique Rojo Baio

Received in: 10-4-2021

Accepted in: 12-8-2021
} 
and absorption and the coherence between nutrient supply and crop demand (Dobermann \& Cassman, 2002). A promising alternative considering the spatial variability is the adoption of PA, which employs variable management practices within production areas according to the location or soil conditions (Beckie et al., 1997). Therefore, PA is an essential tool for fertilizer management through the application at a varying rate (Colaço \& Molin, 2017; Haneklaus \& Schnug, 2000), providing farmers with opportunities to change the distribution and the schedule of applications of fertilizers and other agrochemicals based on spatial and temporal variability in production areas (Zhang et al., 2002).

Considering the importance of knowledge on sitespecific nutrient management strategies, this systematic literature study (SLS) had as its primary focus to identify studies published in this area of interest, especially N, P, and K. For this, three techniques were used:

1. Systematic literature mapping (SLM) identifies studies in a given subject by choosing keywords and conducting database searches. It is a bibliographic survey technique capable of assisting the researcher in carrying out a survey of published research in the area of interest, designed to give an overview of the studied area (Keele, 2007). Researchers have used it from different fields, using other guidelines or methods (Petersen et al., 2015). The SLM technique allows the identification of evidence gaps and evidence groupings in the set of articles that will be used for systematic review (Keele, 2007), which facilitates the identification of areas where primary studies are needed and areas in which systematic literature reviews (SLR) are more pertinent. Thus, SLM can be seen as a precursor to SLR, functioning as a high-level map, generally presented as a set of tables and graphs to synthesize the status of scientific works on a determined research area (Febrero et al., 2014);

2. Snowballing (SB) expands the initial selection by adding new references to the classification process by consulting the references of the selected studies (Wohlin, 2014). In this study, snowballing was used as a complementary strategy to increase the efficiency and quality of the search, reducing the chances of obtaining a search bias (Cohen \& Arieli,
2011), in addition to rescuing important classic texts associated with conventional agriculture. The process can be performed as backward (BSB) or forward snowballing (FSB). BSB includes new studies on the subject from the list of references raised in the initial SLM phase. FSB is the inclusion of new articles from the reference list of studies selected through BSB (Jalali \& Wohlin, 2012);

3. Systematic literature review (SLR) summarizes the studies identified with SLM and SB. According to Petersen et al. (2015), SLM is used to structure a research area, while SLR focuses on collecting and synthesizing evidence.

\section{Review}

\section{Search methods}

Step 1 - Systematic literature mapping (SLM): The SLM technique employed the following steps: a) definition of keywords, b) definition of scientific bases, c) determination of the study selection criteria, d) analysis of studies and e) methodology of synthesis (Keele, 2007; Talavera et al., 2017). below:

The keywords were defined based on the questions

Question 1: What are the basic principles needed to make a fertilizer recommendation in PA?

Question 2: What are the existing methods for recommending fertilizers?

Question 3: What are the existing fertilizer recommendation software?

Six keywords (variable-rate application, nutrient recommendation, fertilizer recommendation, precision agriculture, site-specific management, and software) were chosen, from which nine search expressions were defined, being applied to the research carried out in the four selected scientific bases (Scopus, Science Direct, Web of Science, and Wiley), totaling 36 searches. The same pattern was followed for all bases in order not to distort the results.

The articles were accessed through the Coordination for the Improvement of Higher Education Personnel (CAPES) portal on the remote access platform of the Federated Academic Community (CAFe). The performed processes are shown in the workflow in Figure 1. 


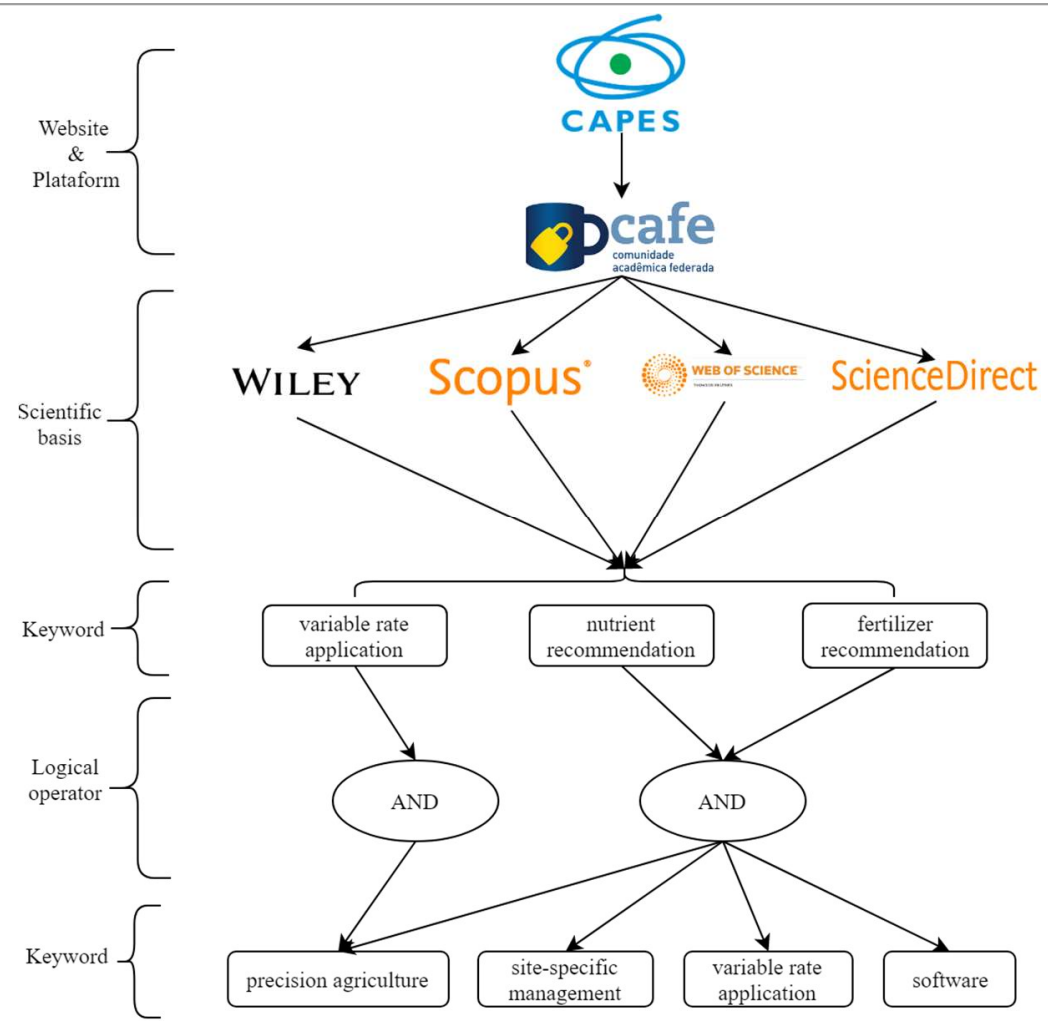

FIGURE 1. Workflow applied to systematic literature mapping.

This mapping covered the entire period available in the search bases without establishing search limits. The results found by cross-checking each keyword were exported in a spreadsheet format, and the information described in Table 1 was extracted.

TABLE 1. Pattern of information extracted from scientific bases.

\begin{tabular}{|c|c|}
\hline Information & Description \\
\hline Title & Research title \\
\hline Authors & Members who are part of the survey \\
\hline Journals & Form of publication of the research \\
\hline Volume & Volume of the published journal \\
\hline Country & $\begin{array}{l}\text { Country in which the research } \\
\text { was developed }\end{array}$ \\
\hline Year & Year of publication of the research \\
\hline Abstract & Main research information \\
\hline DOI & Digital object identifier \\
\hline
\end{tabular}

Step 2 - Snowballing (SB): There is always the possibility that relevant studies may not appear in the search results because they do not have the used search terms. This occurrence can be mitigated through the snowballing sampling technique, verifying the references cited in the studies surveyed by SLM, considering its thematic adequacy and citation frequency (Petersen et al., 2015). The search was carried out in two stages (Wohlin, 2014):

1) Backward snowballing (BSB): the studies cited in the references of the articles selected in the last step of SLM (selection of articles after reading the abstracts, SAR) were consulted seeking to identify relevant new studies to complement the mapping;

2) Forward snowballing (FSB): the studies cited in the references of the studies selected in the previous step (BSB) were consulted, aiming to identify complementary references to them. This step was repeated until the exhaustion of relevant new articles. The selection flow of studies used in the systematic literature study (SLS) is shown in Figure 2. Table 2 presents the articles identified as relevant to the object under study at each selection process step. 


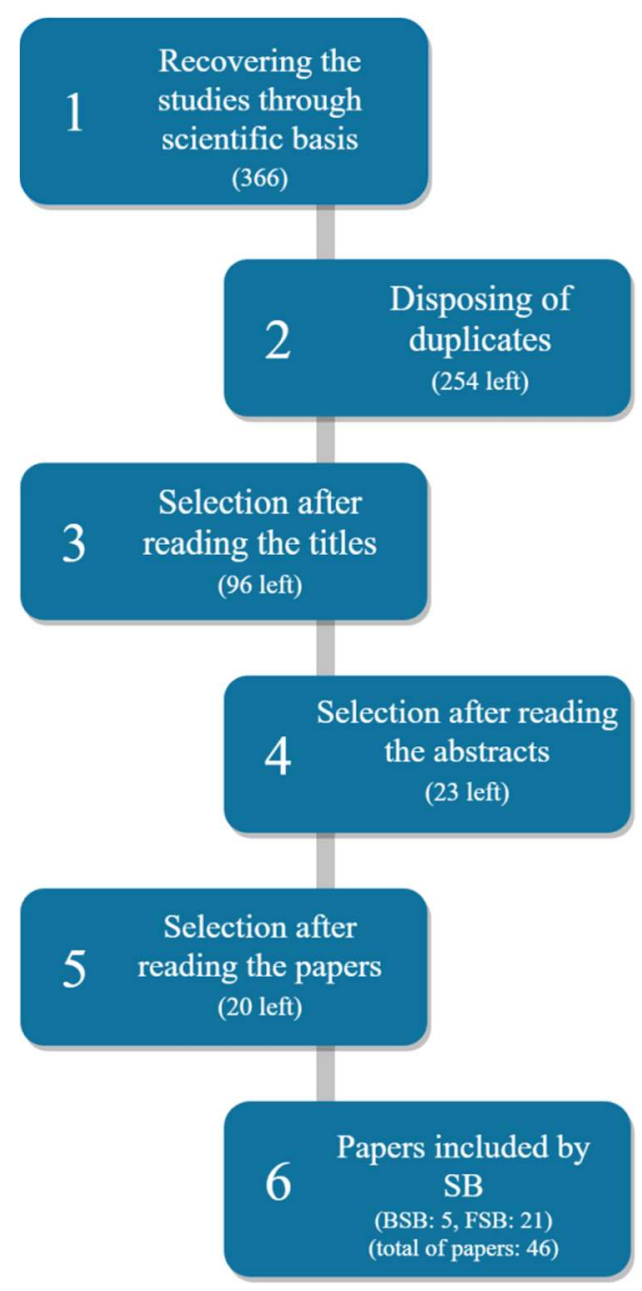

FIGURE 2. Flow of selection of studies used in the systematic literature study (SLS).

TABLE 2. Grouping of studies selected by research technique type.

\begin{tabular}{|c|c|}
\hline Technic & Studies references \\
\hline $\begin{array}{l}\text { Systematic literature } \\
\text { mapping (SLM) }\end{array}$ & $\begin{array}{l}\text { (Basso et al., 2007; Devkota et al., 2016; Frogbrook et al., 2006; Goulding, 2016; Haneklaus \& } \\
\text { Schnug, 2000; Kahabka et al., 2004; Khanna et al., 2000; Lambert et al., 2007; Lv \& Chen, 2009; } \\
\text { Nogara Neto et al., 2011; Olfs et al., 2005; Sapkota et al., 2014; Schirrmann \& Domsch, 2011; Shukla } \\
\text { et al., 2017; van Raij, 1983; van Raij et al., 2002; Wong et al., 2001; Wood \& Litterick, 2017; Xu et } \\
\text { al., 2014, 2017) }\end{array}$ \\
\hline $\begin{array}{l}\text { Backward Snowballing } \\
\text { (BSB) }\end{array}$ & $\begin{array}{l}\text { (Amaral \& Molin, 2011; Buresh et al., 2010; Colaço \& Molin, 2017; Duchesne et al., 2013; Stanger } \\
\text { \& Lauer, 2008) }\end{array}$ \\
\hline $\begin{array}{l}\text { Forward Snowballing } \\
\qquad \text { (FSB) }\end{array}$ & $\begin{array}{l}\text { (Arregui et al., 2006; Birrell et al., 1996; Blackmer, 1997; Bray \& Kurtz, 1945; Coelho et al., 1992; } \\
\text { Csathó et al., 2009; Dinnes et al., 2002; Dobermann \& Cassman, 2002; Hinsinger, 2001; Hoeft \& } \\
\text { Peck, 1998; Janssen et al., 1990; Johnston et al., 2014; Molin et al., 2010; Pampolino et al., 2012; } \\
\text { Pierce \& Nowak, 1999; Raun \& Johnson, 1999; Rehm et al., 2006; Silva \& Raij, 1999; van Es et al., } \\
\text { 2005; Vollmer-Sanders et al., 2016; Wong et al., 2000) }\end{array}$ \\
\hline
\end{tabular}

Figure 3 shows the studies distributed in chronological order, with a maximum of four articles published in 2002 and 2017. 


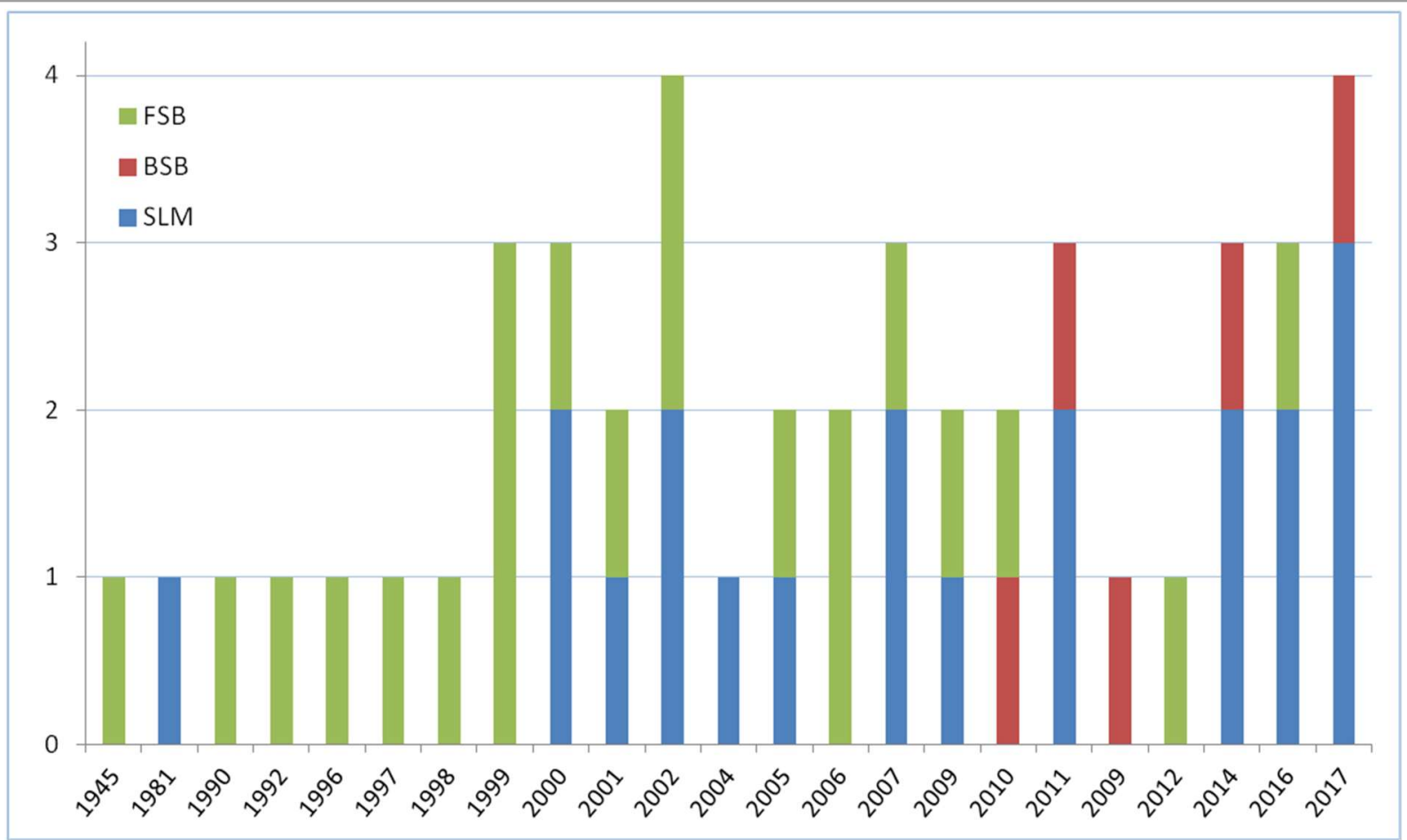

FIGURE 3. Scientific articles distributed in chronological order. SLM - Systematic literature mapping; BSB - Backward snowballing; FSB - Forward snowballing.

Regarding the geographic distribution (the Antarctica continent was excluded) of surveys (Figure 4), the African continent was the only one that did not present articles focused on the researched themes. Still, the American continent presented the highest number (52\% of the total). The United States, with 33\%, was the country (place of publication) with the largest number of research related to the terms searched, which is in line with its world leadership in exports of agricultural products. Brazil is in second place, with $17 \%$ of the research. Regarding the means of diffusion (Table 3), the journals Precision Agriculture, Agronomy Journal, Communications in Soil Science and Plant Analysis, European Journal of Agronomy, Field Crops Research, Plant and Soil, and Soil Use and Management presented more selected articles. Only journals from which more than one study was taken were listed, while the rest were grouped under the item "others".

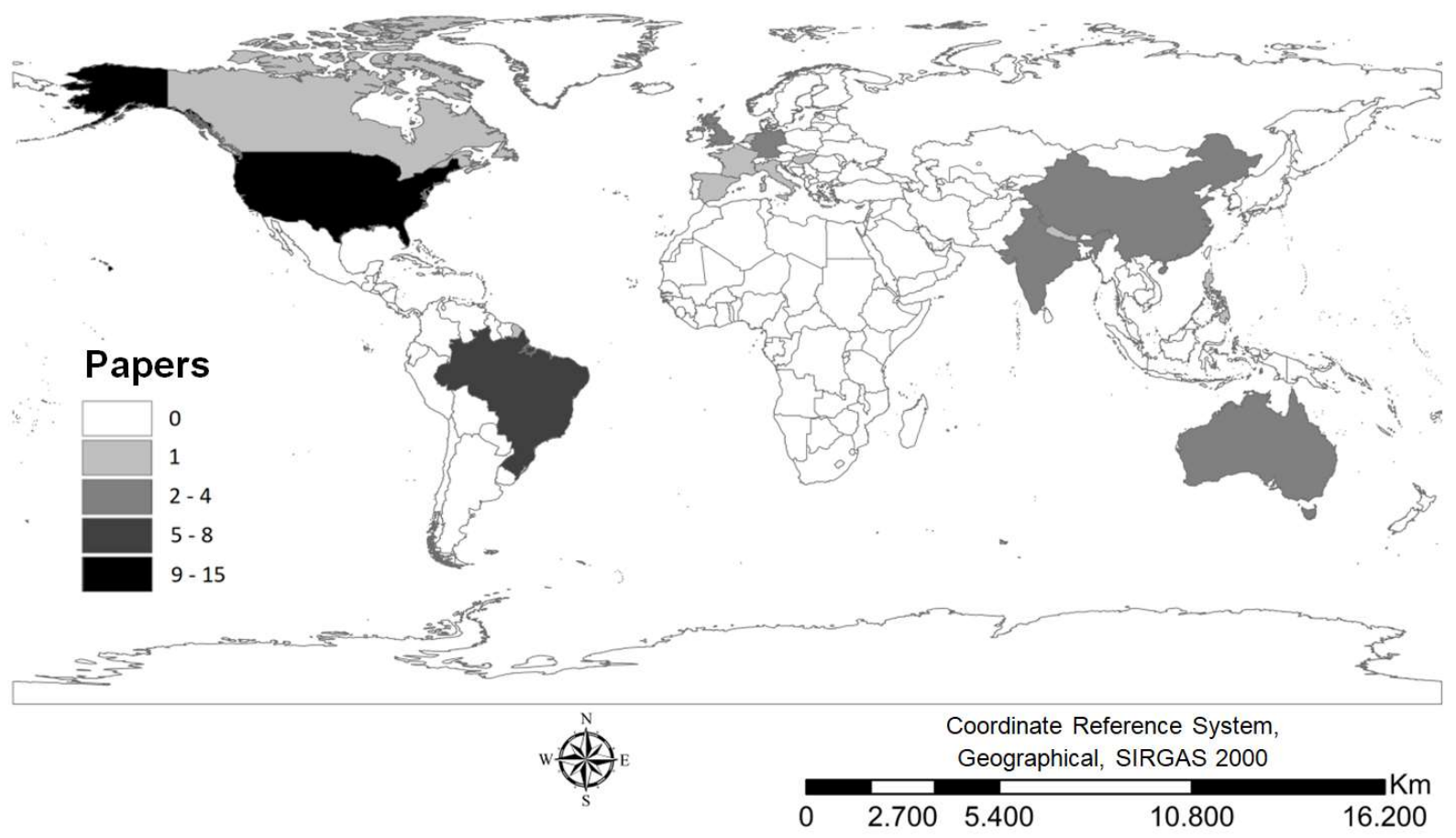

FIGURE 4. Distribution of the number of articles by country of publication. 
TABLE 3. Scientific journals in which the retrieved studies were published.

\begin{tabular}{lc}
\hline Scientific journals & $\begin{array}{c}\text { Number of } \\
\text { articles }\end{array}$ \\
\hline Precision Agriculture & 4 \\
Agronomy Journal & 3 \\
$\begin{array}{l}\text { Communications in Soil Science and Plant } \\
\text { Analysis }\end{array}$ & 3 \\
European Journal of Agronomy & 3 \\
Field Crops Research & 3 \\
Plant and Soil & 3 \\
Soil Use and Management & 3 \\
Agricultural Economics & 2 \\
Journal of Plant Nutrition and Soil & 2 \\
Science & 2 \\
Pesquisa Agropecuária Brasileira & 2 \\
Revista Brasileira de Ciência do Solo & 16 \\
Others &
\end{tabular}

Step 3 - Systematic literature review (SLR): After selecting the relevant research for this study through SLM and SB processes, the SLR technique was performed, synthesizing the most pertinent information from each study.

\section{RESULTS}

The studies were synthesized and classified by subject for the literature review development. The established subjects were divided into five domains: precision agriculture, soil fertility, site-specific nutrient application, fertilizer recommendation methods, and recommendation software for site-specific nutrient application. The results are shown in Figure 5 and summarized in Table 4. The largest number of studies is related to fertilizer recommendation methods (49\%), followed by the topic site-specific nutrient application, which represented $20 \%$ of the analyzed articles, recommendation software for site-specific nutrient application (11\%), and soil fertility and precision agriculture $(10 \%)$. Some studies are related to more than one domain and, therefore, they were counted more than once.

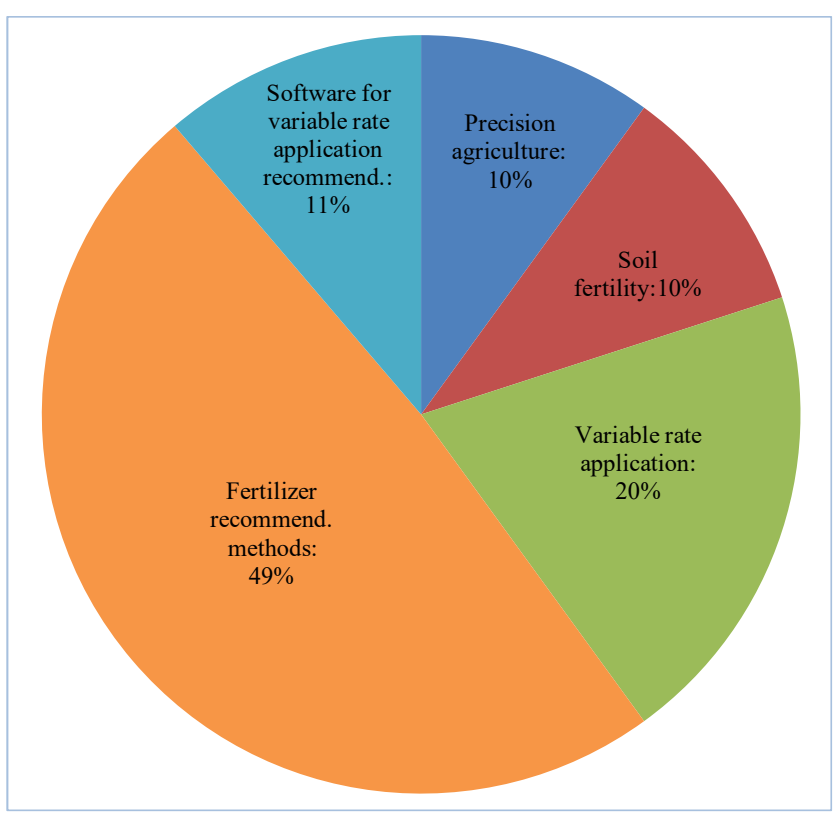

FIGURE 5. Percentage of articles by the predominance of subjects.

TABLE 4. Distribution of studies by study domain.

\section{Domain}

Precision agriculture

Soil fertility

Site-specific application

Fertilizer recommendation methods

Recommendation software for localized application of nutrients
(Ayoubi et al., 2012; Lambert et al., 2007; Robert, 2002; Sapkota et al., 2014; Schirrmann \& Domsch, 2011; van Raij et al., 2002; Verhagen et al., 1995; Verhagen, 1997)

(Chen et al., 2009; Frogbrook et al., 2006; Goulding, 2016; Molin et al., 2010; Schnug et al., 1998; Shukla et al., 2017; Wood \& Litterick, 2017; Ziadi et al., 2013)

(Atherton et al., 1999; Basso et al., 2007; Beckie et al., 1997; Bullock \& LowenbergDeBoer, 2007; Devkota et al., 2016; Haneklaus \& Schnug, 2000; Jin \& Jiang, 2002; Kahabka et al., 2004; Khanna et al., 2000; Lambert et al., 2007; Meyer-Aurich et al., 2010; Molin et al., 2010; Nogara Neto et al., 2011; Robertson et al., 2012; Schnug et al., 1998; Stępień et al., 2013)

(Adams et al., 2000; Amaral \& Molin, 2011; Arregui et al., 2006; Beckie et al., 1997; Buresh et al., 2010; Coelho et al., 1992; Colaço \& Molin, 2017; Csathó et al., 2009; Dinnes et al., 2002; Elprince, 2009; Francis et al., 1993; Hinsinger, 2001; Hoeft \& Peck, 1998; Kersebaum et al., 2005; Lambert et al., 2007; Liu et al., 2006; B.-L. Ma et al., 2014; B. L. Ma et al., 2010; Martha et al., 2004; Olfs et al., 2005; Omafra, 2005; Pierce \& Nowak, 1999; Rajsic \& Weersink, 2008; Raun et al., 2002; Raun \& Johnson, 1999; Rehm et al., 2006; Shanahan et al., 2008; Shapiro et al., 2008; Silva \& Raij, 1999; van Es et al., 2005; van Raij, 1983; Wong et al., 2001; Xu et al., 2014, 2017; Ziadi et al., 2012)

(Buresh et al., 2010; Csathó et al., 2009; IRRI, 2010; Janssen et al., 1990; Pampolino et al., 2012; Sapkota et al., 2014; Xu et al., 2014, 2017) 


\section{Precision agriculture}

According to Robert (2002), the first applications of the site-specific management (SSM) concept, also called PA, through site-specific application were performed in the Midwest, Plains, and Northwest regions of the USA in maize (Zea mays L.), soybean (Glycine max (L.) Merr.) and wheat (Triticum aestivum L.). The site-specific management of agricultural areas is considered a more efficient alternative than conventional methods due to the heterogeneity of agricultural areas and, consequently, agricultural production. SSM uses the spatial variability of soil attributes to direct the necessary inputs to correspond to this variability (Khanna et al., 2000). Verhagen et al. (1995) and Verhagen (1997) pointed out that crop development presents variability in the field due to the variation in soil type and fertility, the existence of compacted layers, moisture, pests, and diseases. Thus, geostatistical techniques offer alternative methods than the conventional statistics for estimating parameters and their associated variability (Ayoubi et al., 2012).

PA is a management strategy that gathers, processes, and analyzes temporal, spatial, and individual data and combines them with other information to support management decisions according to the estimated variability to improve efficiency in the use of resources, yield, quality, profitability, and sustainability of agricultural production (ISPA, 2019). According to Robert (2002), PA was initiated in the mid-1980s to improve fertilizer application, varying rates, and mixtures as needed in the field, being adapted to various practices, crops, and countries. However, the author cited the socioeconomic (costs and lack of skills of the workforce), agronomic (lack of basic information, inadequate sampling procedures and management practices, absence of recommendations for site-specific fertilizer application, and lack of specialized agronomists), and technological factors (agricultural equipment, sensors, and software) as main challenges that limit its wider adoption. Miao et al. (2018) observed that the challenges mentioned above by Robert (2002) are still delaying the adoption of PA in world agriculture.

Bearing in mind that agricultural activities seek to balance the production system and profitability, fertilization is considered one of the main factors that favor higher profits, and the higher the deficiency of nutrients, the more profitable their replacement is (van Raij et al., 2002). For this, the authors have reported that conducting soil analyses is an essential step for a better understanding of soil fertility, and thus, the decision on the possible fertilizer recommendation. However, the costs of soil chemical analysis are expensive to the point of being economically unfeasible for site-specific nutrient application in low value-added crops.

Sapkota et al. (2014) conducted a study in India and found that making fertilization recommendations based on crop response in large areas, disregarding the existing spatial variability, is a methodology that generates losses due to over-application in some parts and deficiency in others the same area. Thus, the authors evaluated nutrient management using Nutrient Expert, a computer-based decision support tool for site-specific nutrient management that estimates the potential yield and generates a specific nutrient recommendation for each location. They found an increase in yield and higher efficiency in nutrient application and profitability compared to the nutrient management practice commonly used by farmers.

Schirrmann \& Domsch (2011) analyzed thematic maps of $\mathrm{pH}, \mathrm{P}, \mathrm{K}$, and $\mathrm{Mg}$ of German soils for 25, 50, and 100-m distance grids between samples, besides on-the-go sampling. The authors verified that the maps elaborated based on on-the-go sampling and $25-\mathrm{m}$ regular grid sampling revealed more suitable spatial characteristics for fertilization at a varying rate than maps derived from the standard sampling methodology that uses 50 or $100 \mathrm{~m}$. In addition, they obtained higher precision for calculating fertilizer requirements ( $40 \%$ or more), reducing over-andunder fertilization.

\section{Soil fertility}

The chemical elements essential to crop development can be classified into two major groups: macronutrients and micronutrients. Nitrogen (N), phosphorus $(\mathrm{P})$, potassium $(\mathrm{K})$, magnesium $(\mathrm{Mg})$, calcium $(\mathrm{Ca})$, and sulfur $(\mathrm{S})$ are required at higher amounts by plants, which is why they are known as macronutrients. On the other hand, micronutrients are demanded at lower doses, although also crucial for crop development. The main micronutrients are boron $(\mathrm{B})$, chlorine $(\mathrm{Cl})$, copper $(\mathrm{Cu})$, iron $(\mathrm{Fe})$, manganese $(\mathrm{Mn})$, molybdenum (Mo), and zinc (Zn) (Mahler, 2008).

The use of nutrients in agriculture must be in line with sustainable agriculture to guarantee current and future human needs for food or other agricultural goods while preserving environmental quality and natural resources. However, agricultural fields have been considered homogeneous for a long time, allowing agricultural activities to represent areas with agricultural inputs on a fixed scale without considering their variability. In addition, soils are not static and homogeneous in space and time, and the standard approach of uniform input application always results in an excessive or insufficient supply at each location in the area, causing unnecessary environmental burdens (Schnug et al., 1998).

Understanding and measuring spatial variability regarding the amount of nutrients available in the soil is crucial to defining site-specific fertilizer management strategies to increase production efficiency and sustainability of agricultural production. Therefore, management with the use of nutrients at a varying rate becomes a viable alternative to reduce the heterogeneity of soil attributes (Shukla et al., 2017). Also, the authors highlighted the possibility of subdividing the area into smaller sub-areas, called management zones, each of them with homogeneous characteristics and, therefore, internally expressing similarity regarding the limiting factors of production. The use of management zones for site-specific fertilizer application requires measuring the spatial variability of nutrients, usually performed by soil sampling (Stępień et al., 2013).

Site-specific nutrient application to be successful depends on accurate soil nutrient maps, usually developed from grid samples. The interpretation of soil nutrient maps should consider the level of confidence associated with the estimated values and the maps should not be automatically accepted as a true representation of the actual conditions in 
the field. It will not be possible to accurately evaluate the spatial relationship of nutrients and yields in the soil if nutritional patterns are not accurately determined (Birrell et al., 1996).

Frogbrook et al. (2006) evaluated crop yield's spatial and temporal variability relative to nutrient conditions $(\mathrm{K}$, $\mathrm{Mg}$, and $\mathrm{P}$ ) and soil $\mathrm{pH}$. They observed that the relationship between crop yield and measured soil properties was generally weak. However, they found that information on the scale of variation of soil chemical properties could be derived from yield maps, which can also be used to guide the sample density of soil properties. The authors also found that the stability observed in the variation structure (semivariogram) of soil $\mathrm{pH}$ and nutrients is important for PA and that this information can be used for at least the next two to three years after its identification.

Ziadi et al. (2013) evaluated the influence of soil texture class on $\mathrm{N}$ application in the maize crop and reported that the different soil textures had a significant effect on maize yield and $\mathrm{N}$ absorption, and, in general, both $\mathrm{N}$ absorption and yield were higher in the sandy soil than in the clay soil.

\section{Site-specific nutrient application}

The adoption of technologies from the PA system was an important innovation in the agricultural production system in this century. It allowed soil horizons and plant analyses to be expanded, converting the spatial variability of soil and crop characteristics into a process of spatially variable entry of agricultural resources that meet local demand, promoting higher efficiency in their use and reducing losses, especially fertilizers (Haneklaus \& Schnug, 2000).

The PA implementation involves using one or more of the following technologies: vehicle guidance for field operations, including controlled traffic agriculture, yield monitoring, and application of agricultural chemicals, mainly fertilizers (Robertson et al., 2012).

The basic principle of variable rate technology (VRT) is to adjust each agricultural input based on each field operation unit's specific condition. Therefore, it must be adaptable to any crop production system, with the required adjustment of specific techniques (Jin \& Jiang, 2002). In addition, the ideal fertilizer application rate varies strongly over time and is difficult to predict exactly (MeyerAurich et al., 2010).

The most critical stage related to the use of PA refers to decision-making about soil and plant attributes, which must be considered for the adoption of strategies that should lead to an increase in the system efficiency (Nogara Neto et al., 2011). For this, different studies reported in the literature have shown the efficiency of using PA to improve production, namely:

Nogara Neto et al. (2011) carried out a study on spatially distributed soil and crop attributes related to maize yield and observed the viability of PA as a tool that enabled decision making based on statistical tools, generating strategies that allowed an increase in the crop yield potential and an optimization of the used inputs. Jin \& Jiang (2002) observed that higher yields were obtained with specific recommendations of varying rates defined for each farmer and that the differences in income between farmers were smaller among those who used varying rates than the traditional recommendations.
Nogara Neto et al. (2011) observed spatial variation in the maize crop yield, described the steps to identify the soil and crop attributes responsible for this variability, and outlined a strategy to increase the efficiency of the production system. According to the authors, soil attributes were the main responsible for this variability, and the elements $\mathrm{P}$ and $\mathrm{Mg}$ were considered critical in terms of the variability management in the analyzed area. Moreover, the regression tree and cluster analysis applied to the data defined the strategies to be adopted. In this case, $\mathrm{Mg}$ was the element responsible for the highest variation in yield in the area.

Lambert et al. (2007) mentioned some impasses for soil fertility management due to the heterogeneous transport of some nutrients, such as P. This element is irregularly transported in the soil from one year to another, mainly because of the topographic and chemical characteristics of the soil. The authors explained that a uniform application of this fertilizer would not be recommended due to this heterogeneous behavior, as the same area may present an immediate availability after the fertilizer application, or the availability may be difficult or even impossible due to characteristics such as $\mathrm{pH}$, clay content, and organic matter. Therefore, applying a uniform rate can cause an excess of the nutrient in some parts and nutritional deficiency in others, reducing the crop yield.

Haneklaus \& Schnug (2000) dealt with the promising use of PA in agricultural management, pointing to a trend that the technologies of this system are increasingly present and, therefore, the strategies for decision making in the fertilizer application at a varying rate have become increasingly recommendable and justifiable. Farmers can use technologies to improve fertilizers in their area, thereby reducing or avoiding losses. To this end, they can use information from the crop response implanted in the areas to nutrient inputs and dynamics over time by using the variable rate technology (Lambert et al., 2007).

Molin et al. (2010) evaluated the performance of fertilizer application at variable rates, in which the PA techniques are practical and promising for long-term evaluation in coffee. Although the research was carried out only on coffee, the authors extrapolated the conclusions to other perennial crops. Applications of $\mathrm{P}$ and $\mathrm{K}$ resulted in an increase of $34 \%$ in crop yield, with savings of $23 \%$ in phosphate fertilizers and $13 \%$ in potassium fertilizers compared to the fixed fertilization rate. Nogara Neto et al. (2011) found differentiated yield for the maize crop in plots of the same agricultural area and proposed that these results reaffirm the need to adopt site-specific management, as recommended by the PA methodology.

Studies developed by Lowenberg-DeBoer \& Aghib (1999) showed that the management of agricultural areas through the application at a varying rate did not reduce the applied volume of fertilizers, in some cases even higher than the uniform application. However, the authors concluded that the main effect of the applied fertilizers $\left(\mathrm{P}_{2} \mathrm{O}_{5}\right.$ and $\left.\mathrm{K}_{2} \mathrm{O}\right)$ was their redistribution within the field. Rejesus \& Hornbaker (1999) corroborated these results: a soil region with higher yield probably requires lower amounts of fertilizers, and an area with lower yield probably requires higher fertilizer application. In this sense, the inputs are reallocated as a function of spatial variability. 


\section{Models for fertilizer recommendation}

Soil fertility management requires an understanding of the nutrient availability and distribution in the cultivated area. Thus, this survey identified and structured the fertilizer recommendation methods according to the nutrients most required by crops: $\mathrm{N}, \mathrm{P}$, and $\mathrm{K}$ (Table 5).

The studies present particularities in developing recommendation methods, considering that each geographic region has its characteristics (e.g., physical, chemical, biological, climatic, and pedological). According to Elprince (2009), fertilizer recommendations usually depend on field trials, where the crop response is measured, minimizing the spatial variability of each variable with the potential to affect crop yield, except for the nutrient in question. In addition, the recommendations take into account crop requirements, and even though the prices are publicly available to farmers from government agencies, they still tend to apply more inputs than suggested (Liu et al., 2006). Therefore, the main characteristics intrinsically interconnected and directly influence the recommendation methods are the geological formation, climate, and production system, considering that each region has a different characteristic.

TABLE 5. Studies related to the recommendation methods for nitrogen, phosphorus, and potassium.

\begin{tabular}{cl}
\hline Nutrients & \multicolumn{1}{c}{ Studies authors } \\
\hline \multirow{3}{*}{ Nitrogen } & (Adams et al., 2000; Amaral \& Molin, 2011; Arregui et al., 2006; Blackmer, 1997; Coelho et al., 1992; \\
& Colaço \& Molin, 2017; Csathó et al., 2009; Dinnes et al., 2002; Francis et al., 1993; Hoeft \& Peck, 1998; \\
& Kersebaum et al., 2005; Lambert et al., 2007; B. L. Ma et al., 2010; Martha et al., 2004; Olfs et al., 2005; \\
& Omafra, 2005; Pierce \& Nowak, 1999; Raun \& Johnson, 1999; Rehm et al., 2006; Shanahan et al., 2008; \\
& Shapiro et al., 2008; van Es et al., 2005; van Raij, 1983; Xu et al., 2014, 2017; Ziadi et al., 2012) \\
\hline \multirow{2}{*}{ Phosphorus } & (Buresh et al., 2010; Colaço \& Molin, 2017; Csathó et al., 2009; Hinsinger, 2001; Johnston et al., 2014; \\
& Lambert et al., 2007; Rehm et al., 2006; Shapiro et al., 2008; Silva \& Raij, 1999; Wong et al., 2001; \\
\hline \multirow{2}{*}{ Potassium } & Xu et al., 2017) \\
\hline & (Buresh et al., 2010; Colaço \& Molin, 2017; Csathó et al., 2009; Rehm et al., 2006; Shapiro et al., 2008; \\
\hline
\end{tabular}

The SLS technique selected 39 studies on nutrient recommendation methods for crops, in which 62,23 , and $15 \%$ of the articles are related to recommendation methods for $\mathrm{N}, \mathrm{P}$, and $\mathrm{K}$, respectively. Also, the recommendation of more than one of the nutrients was present in some studies, then counted more than once to calculate the percentages.

\section{Nitrogen}

Nitrogen is a notable element in several aspects and has a completely different behavior from $\mathrm{P}, \mathrm{K}$, limestone, and $\mathrm{Mg}$. It is the most expensive nutrient, being required in higher amounts by most crops (Stanger \& Lauer, 2008; van Raij, 1983). Moreover, nitrogen is one of the inputs that attracts the greatest attention of researchers when considering the variable crop response due to their complex dynamics in the soil (Amaral \& Molin, 2011). Variations in drainage and soil texture within production areas are believed to cause localized differences in soil $\mathrm{N}$ availability and, therefore, are a potential basis for fertilizer application at a varying rate (van Es et al., 2005). However, the recommendation of nitrogen fertilizers for maize remains uniform in most cultivated fields in the USA and Canada (Omafra, 2005). According to Adams et al. (2000) and Raun et al. (2002), $\mathrm{N}$ is applied uniformly in the field, although it is known that the actual requirements for $\mathrm{N}$ vary substantially on this scale due to differences in potential yield, soil $\mathrm{N}$ availability, mineralization, and fertilizer use efficiency. Shanahan et al. (2008) emphasized that without tools to meet the requirements for $\mathrm{N}$ at a varying rate, farmers tend to apply this nutrient at uniform doses to meet the crop requirements in the most demanding areas of the field, resulting in a higher risk of $\mathrm{N}$ loss.
Nitrogen fertilization is essential for profitable maize production. However, it is also important in the production cost and can contribute to the degradation of the environment. Economic and environmental costs of nitrogen fertilization are more important than in the past and are likely to become even more important in the future. These costs provide compelling reasons to intensify efforts to improve $\mathrm{N}$ management practices (Blackmer, 1997).

Nutrient transfer rates are heterogeneous due to local topographic and chemical variations in the soil (Lambert et al., 2007). According to Shanahan et al. (2008), management strategies for $\mathrm{N}$ are still inefficient, and nitrogen fertilizers applied in production systems have only $33 \%$ utilization. Considering that the cost per ton of nitrogen fertilizer at the time of this survey was $\$ 850.00$ and assuming that $67 \%$ are considered losses, it represented an annual loss of $\$ 28$ billion in agricultural activities.

The primary forms of $\mathrm{N}$ losses are gas emission (Francis et al., 1993), soil denitrification $\left(\mathrm{NO}_{3}{ }^{-}>\mathrm{NO}_{2}{ }^{-}>\right.$ $2 \mathrm{NO}^{-}>\mathrm{N}_{2} \mathrm{O}^{-}>\mathrm{N}_{2}$ ) (Raun \& Johnson, 1999), runoff (Raun \& Johnson, 1999), volatilization (Martha et al., 2004), and leaching (Ma et al., 2010). These losses cause deleterious effects in the soil and the environment, such as soil nitrification by the nitrosation phase, groundwater contamination, soil salinization, increase in nitrous oxide $\left(\mathrm{N}_{2} \mathrm{O}\right)$ in the atmosphere, and base runoff to deep soil layers (Dinnes et al., 2002).

Adopting precise nitrogen fertilizer recommendations can improve fertilizer efficiency, reducing the cost of unnecessary inputs for wheat farmers and the environmental impact of $\mathrm{N}$ losses (Arregui et al., 2006). 
Shapiro et al. (2008) presented fertilizer recommendation methods based on the nutritional requirements of maize according to the expected yield and nutrient contents in the soil, also employing cost and time adjustment factors to calculate the recommended $\mathrm{N}$ rate. Another fertilizer recommendation system was proposed by
Csathó et al. (2009), being favorable to the environment, as it reduced costs and offering specialized guidance on four fertilization levels: 1) minimum, 2) environmentally friendly, 3) balanced, and 4) maximum level of plant nutrition.

Table 6 shows $\mathrm{N}$ recommendation models for different crops.

TABLE 6. Recommendation models for nitrogen fertilizers.

\begin{tabular}{|c|c|c|}
\hline Authors & Nitrogen Fertilizer Recommendation Methods & Crop \\
\hline (Xu et al., 2017) & Fertilizer $N=\frac{Y R_{N}}{A E_{N}}$ & Maize \\
\hline $\begin{array}{l}\text { (Olfs et al., 2005; } \\
\text { Xu et al., 2014) }\end{array}$ & $\operatorname{ANNM}=N_{\operatorname{plant}(H)}+N_{\min (H)}-N_{\operatorname{plant}(V)}-N_{\min (V)}$ & Wheat \\
\hline $\begin{array}{l}\text { (Olfs et al., 2005; } \\
\text { Xu et al., 2014) }\end{array}$ & $A N L\left(N_{\text {loss }}\right)=A N M+N_{\text {fertilizer }}+N_{\text {initial }}-N_{\text {uptake }}-N_{\text {initial }}$ & Wheat \\
\hline (Hoeft \& Peck, 1998) & Fertilizer $N=\left(T Y B \times 1.2 \mathrm{lb} \frac{N}{\text { bushel }}\right)-$ legume $N-$ manure $N$ - incidental & Maize \\
\hline (Colaço \& Molin, 2017) & $N_{-}$rate $_{i}=3.3923 \times$ Yield_exp $i-2.1481 \times N_{\text {leafi }}+86.9155$ & Orange \\
\hline (Shapiro et al., 2008) & $\begin{array}{c}N \text { need }(\mathrm{lb} / \mathrm{ac})=\left[35+(1.2 \times \mathrm{EY})-8 \times \mathrm{NO}_{3}-\mathrm{N} \text { ppm }\right)-0.14 \times E Y \times \\
O M)- \text { other } N \text { credits }] \times \text { Price }_{\text {adj }} \times \text { Timing } \\
\text { adj }\end{array}$ & Maize \\
\hline (Rehm et al., 2006) & $N=1.2 \times Y G-N_{3}-$ other $N$ credits & Maize \\
\hline (Coelho et al., 1992) & $N_{f}=N_{y}-N_{s} / E_{f}$ & Maize \\
\hline (Pierce \& Nowak, 1999) & $N_{j}=\left\lfloor G_{w} \times \frac{1}{\frac{N_{f}}{N_{a v}} \times \frac{N_{a v}}{N_{s}} \times \frac{G_{w}}{N_{t}}}\right]-\left(N_{\text {min }}+N_{\text {in }}\right)$ & $\begin{array}{l}\text { Multiple } \\
\text { crops }\end{array}$ \\
\hline (Csathó et al., 2009) & $N=\left(Y \times S N R_{Y} \times F_{S N S}\right) \pm C$ & Wheat \\
\hline
\end{tabular}

$\mathrm{N}$ rate $\mathrm{i}-\mathrm{N}$ rate at pixel $\mathrm{i}\left(\mathrm{kg} \mathrm{ha}^{-1}\right)$; Yield_exp $\mathrm{i}$ - expected yield at pixel $\mathrm{i}\left(\mathrm{t} \mathrm{ha}^{-1}\right)$; Nleafi $-\mathrm{N}$ leaf level at pixel $\mathrm{i}\left(\mathrm{g} \mathrm{kg}^{-1}\right)$; $\mathrm{EY}_{-}-$expected yield $(\mathrm{lb} / \mathrm{ac}) ; \mathrm{NO}_{3}{ }^{-}-\mathrm{Nppm}$ - mean nitrate- $\mathrm{N}$ concentration in the root zone (2-4 feet deep) in parts per million; OM - percentage of organic matter;

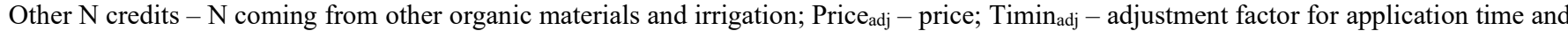
split application; $\mathrm{N}_{\mathrm{f}}-$ required $\mathrm{N} ; \mathrm{G}-$ yield target, $\mathrm{N}_{\mathrm{av}}-\mathrm{N}$ available in the soil in the root zone; $\mathrm{N}$ - prediction of required $\mathrm{N}$ to meet the crop demand; $\mathrm{N}_{\min }-\mathrm{N}$ in the soil provided by net mineralization; $\mathrm{N}_{\text {in }}$ - pre-install inorganic $\mathrm{N} ; \mathrm{Y}-$ expected yield $\left(\mathrm{t}^{-1} \mathrm{a}^{-1}\right) \mathrm{SNR}_{\mathrm{Y}}-$ specific nutrient requirements to achieve expected yield; FSNS - factor dependent on the amount of nutrient in the soil; $\mathrm{C}$ - correction factor; TYB - expected yield in bushels.

The efficient use of nitrogen fertilizers is essential to increase the economic return of maize (Zea mays L.) production and minimize the potential negative effects on the environment (Ziadi et al., 2012). These researchers concluded that the recommended $\mathrm{N}$ rates need to be adjusted considering the type and condition of soil drainage. Moreover, the use of management zones based on the soil texture class or other auxiliary variables, such as soil electrical conductivity, can guide soil sampling and establish specific $\mathrm{N}$ recommendations to reduce production costs and environmental losses. Also, the residual soil nitrate can be reduced when the $\mathrm{N}$ application is based on the soil texture class and ideal $\mathrm{N}$ rate. In this sense, the spatial and temporal variability of nutrient supply and demand for crops is important in $\mathrm{N}$ management dynamics to avoid groundwater contamination (Kersebaum et al., 2005).

$\mathrm{Ma}$ et al. (2014) estimated the need for $\mathrm{N}$ application to maize-based on canopy reflectance and concluded that the single-dose pre-planting application $\left(180 \mathrm{~kg} \mathrm{~N} \mathrm{ha}^{-1}\right)$ was less efficient than its split application, with a lower dose applied at sowing $\left(30 \mathrm{~kg} \mathrm{~N} \mathrm{ha}^{-1}\right)$, followed by another application after mapping between vegetative stages V6 and V8 (with a mean rate of $80 \mathrm{~kg} \mathrm{~N} \mathrm{ha}^{-1}$ ). The results also showed that N's variable and uniform application strategies required less fertilizer and reached equivalent yield with higher nitrogenuse efficiency (NUE) than the single-dose pre-planting application. Compared to unfertilized or fully fertilized treatments, the improvement in yield and NUE of the variable rate strategy was mainly due to the second topdressing application compared to the variation in the applied $\mathrm{N}$ rates. Furthermore, both application strategies (variable and uniform) reduced the spatial variability of mineral soil $\mathrm{N}$ and yield compared to the treatment without fertilization.

Olfs et al. (2005) evaluated the $\mathrm{N}$ recommendation based on soil and plant for European agricultural conditions and concluded that multiple $\mathrm{N}$ applications instead of a single pre-planting application should be considered, as yields in the field presented temporal and special variability, 
and excessive/deficient $\mathrm{N}$ applications are unacceptable from both an ecological and an economic point of view. They also warn that $\mathrm{N}$ doses should be split mainly for cereals, which allows achieving maximum efficiency in using these fertilizers.

The amount of $\mathrm{N}$ applied to winter wheat in the Mediterranean region must be carefully managed to avoid yield restrictions and guarantee grain quality. Nitrogen losses in the soil-plant system are high when its application is not synchronized with the crop demand, leading to low fertilizer absorption efficiency. Precise nitrogen recommendations can improve fertilizer efficiency, reducing unnecessary input costs for wheat farmers and the environmental impact of $\mathrm{N}$ losses (Arregui et al., 2006).

Rajsic \& Weersink (2008) examined why farmers are apparently applying $\mathrm{N}$ at levels that exceed those suggested by government extension services in many Canadian regions. One of the main reasons why farmers would apparently waste money applying more fertilizer than a crop can absorb is the perception that general recommendations are not appropriate for their situations. The authors estimated the economically ideal $\mathrm{N}$ application rates in maize for seven locations in Ontario over several years using four yield response models. The recommended rate was higher than the maximum economic rate of nitrogen (MERN) in most examined locations. They also found that the difference between the recommended rate based on the average and MERN (estimated by the functional forms) was positively correlated with the yield potential, leading to the conclusion that the recommendation based on the average estimate underestimates the potential of less productive locations, which could present higher yields with sufficient $\mathrm{N}$ availability. Furthermore, the authors reported that farmers need to know the soil $\mathrm{N}$ content before fertilization to evaluate the economically optimal $\mathrm{N}$ rate. This measurement in Canada would cost \$ $25 \mathrm{ha}^{-1}$.

\section{Optical sensors for nitrogen fertilization}

Recommendations for nitrogen fertilizers are generally based on $\mathrm{N}$ measurements in the soil, but several technologies have been developed to assist in the management of $\mathrm{N}$ in crops. Among these technologies, the use of optical sensors has the potential to recommend, in real-time, the need for $\mathrm{N}$ based on the variability of crops. According to Kersebaum et al. (2005), these tools seek to detect the crop $\mathrm{N}$ status at different stages of development. Schnug et al. (1998) stated that optical sensors were far from being applied to perform measurements of soil texture and nutrients available to plants. However, optical sensors are currently considered a useful tool to assist in the recommendation of nitrogen fertilization. Amaral \& Molin (2011) concluded that optical sensors are a useful tool to assist the topdressing $\mathrm{N}$ recommendation in sugarcane when the spatial variability of its demand is detected based on the crop response, estimated in a strip of sugarcane that has received an adequate $\mathrm{N}$ dose.

Nitrogen recommendation methods using optical sensors are shown in Table 7.

TABLE 7. Nitrogen recommendation method using optical sensors.

\begin{tabular}{ccc}
\hline Authors & Recommendation Methods & Crop \\
\hline (Raun et al., 2002) & $F N R=(G N U P-F N U P) / 0.70$ & Wheat \\
\hline (Ma et al., 2014) & $N_{\text {opt }}=\frac{\left(N_{\max }-N_{\min }\right)}{\exp \left(\frac{S I_{\max }-S I_{\min }}{\beta}\right)} x\left(1-\exp \left(\frac{S I-S I_{\min }}{\beta}\right)+N_{\max }\right)$ & Maize \\
\hline
\end{tabular}

FNR - N fertilizer requirement; FNUP - forage N uptake estimated by NDVI measurement, where $F N U P=b_{0}+b_{1} e^{b 2 N D V I}$; GNUP - forage $\mathrm{N}$ uptake when $\mathrm{N}$ is applied to obtain maximum yield; $\mathrm{N}_{\mathrm{opt}}-$ optimal calculated $\mathrm{N}$ rate; $S I=\frac{N D V I}{N D V I_{\max }} ; \mathrm{N}_{\max }$ and $\mathrm{N}_{\min }-$ maximum and minimum $\mathrm{N}$ rates in the entire area, respectively; $\mathrm{SI}_{\max }$ and $\mathrm{SI}_{\min }-\mathrm{NDVI}$ (normalized difference vegetation index) saturation in the plots that received the maximum and minimum $\mathrm{N}$ rates, respectively; $\beta=0.6$.

\section{Phosphorus}

Recommendation techniques have been essential with the growing demand for phosphate fertilizers by cultivations aiming at optimizing their use. According to Shapiro et al. (2008), phosphate fertilizers can be applied to maize before sowing or distributed in the rows close to the root zone, considering the different soil fertility management systems. In addition, $\mathrm{P}$ incorporation into the soil results in more effective use, leading to a low potential for loss by runoff. Phosphorus applied superficially is usually used more efficiently if sufficient residue coverage to maintain moisture on the soil surface (Shapiro et al., 2008).

However, $\mathrm{P}$ is the least mobile and available to plants under most soil conditions compared to other macronutrients, often limiting plant growth (Hinsinger, 2001). In theory, phosphate fertilizers can be transformed into non-labile $\mathrm{P}$ (not available for plants), and $\mathrm{P}$ accumulation may be difficult due to soil characteristics such as $\mathrm{pH}$, clay content, and organic matter (Lambert et al., 2007).
Another characteristic of P (inorganic) in the soil is its poor mobility due to the reactivity of phosphate ions with the numerous soil constituents, resulting in their retention in the soil colloids. Therefore, only a marginal proportion of the soil $\mathrm{P}$ is present as $\mathrm{P}$ ions in the soil solution (Hinsinger, 2001). In addition, $P$ is usually used inefficiently in agriculture, as field experiments have shown that only 10 to $15 \%$ of the applied volume is absorbed by crops (Johnston et al., 2014).

Thus, the information on the crop response to $\mathrm{P}$ applications and the dynamics of nutrient transition over time allow farmers to manage inputs using variable-rate technologies (VRT) (Lambert et al., 2007).

Some recommendation methods for $\mathrm{P}$ (Table 8) do not use the soil chemical analysis to carry out phosphate recommendation, as the methods proposed by Buresh et al. (2010) and the QUEFTS (quantitative evaluation of the fertility of tropical soils) model (Janssen et al., 1990) used by Buresh et al. (2010). This model employs a linear 
optimization procedure considering the interactions between nutrients to obtain an ideal nutritional balance instead of calculating the requirements for fertilizers $(\mathrm{N}, \mathrm{P}$, and $\mathrm{K}$ ) individually and manually.

Colaço \& Molin (2017) studied site-specific citrus fertilization and developed models for $\mathrm{N}, \mathrm{P}$, and $\mathrm{K}$ recommendation using a bivariate linear regression of the best-expected production response using soil and leaf sampling data and yield maps. Instead of a table of $\mathrm{P}$ recommendations, Shapiro et al. (2008) developed two recommendation models for $\mathrm{P}$ as a function of soil $\mathrm{P}$ content using the Bray-1 method, one for maize after maize and another for maize after soybean.
Another difference is the techniques for measuring soil nutrient content, such as the Mehlich I (Mehlich, 1953), Mehlich II (Mehlich, 1978), Mehlich III (Mehlich, 1984), Olsen (Olsen, 1954), and Bray (Bray \& Kurtz, 1945). The Mehlich I extractor was adopted in Brazil in the 1950s to replace the Bray method, commonly used in the United States. The Bray method has characteristics that make it excellent for estimating $\mathrm{P}$ in the soil, i.e., it extracts the available $\mathrm{P}$ (labile $\mathrm{P}$ : $\mathrm{P}$ bound to $\mathrm{Fe}$ and $\mathrm{Al}$ ), but it does not extract non-available $\mathrm{P}$ (non-labile $\mathrm{P}$ : $\mathrm{P}$ bound to $\mathrm{Ca}$ ). The adoption of Mehlich 1 in Brazil was due to the wide use of natural phosphates, which were not detected by the Bray method (Silva \& Raij, 1999).

TABLE 8. Recommendation models for phosphorus.

\begin{tabular}{|c|c|c|}
\hline Authors & Phosphate Fertilizer Recommendation Methods & Crop \\
\hline (Xu et al., 2017) & $P_{2} O_{5}=\left(\frac{Y R_{P} \times R I E_{P}}{R E_{P}}+A Y \times R I E_{P} \times R I_{P} \times X_{G} \%\right) \times 2.292$ & Maize \\
\hline (Colaço \& Molin, 2017) & $P_{2} O_{5 i}=2.0994 \times$ Yield_exp $i-2.0375 \times P_{\text {soili }}+46.8327$ & Orange \\
\hline (Shapiro et al., 2008) & $\begin{array}{l}P_{2} O_{5}=(25-\text { Bray P ppm }) \times 4 \times 1.1209 \\
P_{2} O_{5}=(17-\text { Bray P ppm }) \times 6 \times 1.1209\end{array}$ & $\begin{array}{l}\text { Continuous maize } \\
\text { Maize after soybean }\end{array}$ \\
\hline (Rehm et al., 2006) & $\begin{array}{l}P_{2} O_{5}=[0.7-0.035 \times(\text { Bray } P \text { ppm })] \times E Y \\
P_{2} O_{5}=[0.7-0.044 \times(\text { Olsen } P \text { ppm })] \times E Y\end{array}$ & Maize \\
\hline (Csathó et al., 2009) & $P_{2} O_{5}=\left(\mathrm{Y} \times \mathrm{SNR}_{Y} \times \mathrm{F}_{S N S}\right)+C$ & Multiple crops \\
\hline (Buresh et al., 2010) & $\left.P_{2} O_{5}=\left(G Y-G Y_{0 P}\right) \times R I E_{P} / R E_{P}\right)$ & Rice \\
\hline
\end{tabular}

$\mathrm{P}_{2} \mathrm{O}_{5}-\mathrm{P}$ requirement $\left(\mathrm{kg} \mathrm{ha}^{-1}\right)$; YRP - yield response to $\mathrm{P}$ fertilizer $\left(\mathrm{kg} \mathrm{ha}^{-1}\right)$; RIEP - reciprocal internal efficiency, which is the nutrient absorption requirement per ton of grain yield $\left(\mathrm{kg} \mathrm{t}^{-1}\right)$; REP - recovery efficiency for P fertilizer application $(\%)$; AY - attainable yield $(\mathrm{kg}$ $\left.\mathrm{ha}^{-1}\right) ; \mathrm{RI}$ - harvest index for $\mathrm{P} ; \mathrm{X}_{\mathrm{G}} \%$ - grain return ratio to ensure the $\mathrm{P}$ balance; 2.292 - conversion constant for $\mathrm{P} ; \mathrm{P}_{2} \mathrm{O}_{5 \mathrm{i}}-\mathrm{P}_{2} \mathrm{O}_{5}$ rate at pixel $\mathrm{i}\left(\mathrm{kg} \mathrm{ha}^{-1}\right)$; Yield exp $\mathrm{i}$ - expected yield at pixel $\mathrm{i}\left(\mathrm{t} \mathrm{ha}^{-1}\right)$; $\mathrm{P}$ soil - soil $\mathrm{P}$ content at pixel $\mathrm{i}\left(\mathrm{mg} \mathrm{dm}^{-3}\right) ; 1.1209$ - constant to convert $\mathrm{lb} / \mathrm{ac}$ into $\mathrm{kg} \mathrm{ha}^{-1} ; \mathrm{EY}$ - expected yield (lb/ac); Y - expected yield $\left(\mathrm{t} \mathrm{ha}^{-1}\right) ; \mathrm{SNR}$ - specific nutrient requirements to achieve expected yield; FSNS factor dependent on the amount of nutrient in the soil; $\mathrm{C}$ - correction factor; GY - grain yield ( $\left.\mathrm{t} \mathrm{ha}^{-1}\right)$; GYOP - grain yield ( $\mathrm{t}$ ha $\left.{ }^{-1}\right)$ in the omission plot (where the required nutrient amount was not applied); RIEp - nutrient recovery efficiency $\left(\mathrm{kg} \mathrm{kg}^{-1}\right)$, determined with QUEFTS (quantitative evaluation of the fertility of tropical soils); REp - recovery efficiency.

\section{Potassium}

Soil minerals are rich in $\mathrm{K}$, although little is available to plants. In addition, $\mathrm{K}$ is present in the soil in many forms. From 1 to $10 \%$ of the total $\mathrm{K}$ in the soil is considered as slowly available. This nutrient is trapped between layers of silica clay and alumina. These clays shrink and swell during the drying and wetting soil cycles. The $\mathrm{K}$ trapped between clay layers is released slowly during the expansion cycle and is unavailable during the drying or contraction cycles. Potassium is an essential mineral nutrient for plants, and its need is only lower than N. Its molecular form absorbed by plants is $\mathrm{K}^{+}$, which is the most important cation for the physiological process of plants. It has an important role as an enzyme activator and in maintaining the cell turgor, as it is directly bound to the $\mathrm{K}$ pump. It is an element of high mobility in plant tissues and very present in the youngest tissues of plants (e.g., meristematic tissues and fruits) (Omafra, 2005).

The main relationship of critical $\mathrm{K}$ levels in the soil is associated with soils with intense weathering. The intensely weathered nature of cultivated soils in Western Australia and the long history of potassium depletion by the agricultural system has resulted in an increased incidence of $\mathrm{K}$ deficiency in wheat. These soils are intensely weathered, and quartz and kaolinite dominate their mineralogy (Wong et al., 2001). Using the Colwell test, a statistical relationship between the need for $\mathrm{K}$ and the $\mathrm{K}$ present in the soil was developed from experimental field data reported in Wong et al. (2000) for the Western Australia wheat belt. In contrast, soils in the USA, especially in Nebraska, can provide $\mathrm{K}$ for excellent maize yields, but $\mathrm{K}$ deficiency in the soil may occur (Shapiro et al., 2008). In Brazil, soils show high weathering due to the location near the equator and the high annual precipitation.

The influence of soil's biological, chemical, and physical processes is important in the nutrient availability and fluctuations in the prices of fertilizers. Thus, it is essential to re-examine the complete maintenance approaches to determine $\mathrm{K}$ and $\mathrm{P}$ fertilizers (Buresh et al., 2010).

The $\mathrm{K}$ recommendation methods selected by SLS (Table 9) were divided into methods for a specific crop (e.g., maize, orange, and rice) and methods for multiple crops. Buresh et al. (2010) stated that algorithms are necessary to determine the appropriate doses of $\mathrm{K}$ fertilizer, which should consider the processes in the soil and its characteristics mediating $\mathrm{K}$ availability to balance profitability in the short term and sustainable yield in the long term. 
TABLE 9. Recommendation models for potassium fertilizers.

\begin{tabular}{|c|c|c|}
\hline Authors & Potassium Fertilizer Recommendation Methods & Crop \\
\hline (Shapiro et al., 2008) & $K_{2} O=\left[125-K_{\text {soil }}(\mathrm{ppm}) \mathrm{K}\right] * 1.12 ;$ se $\mathrm{K}<125$ & Maize \\
\hline (Xu et al., 2017) & $\begin{array}{c}K_{2} O=\left(\left(\frac{Y R_{K} \times R I E_{K}}{R E_{k}}\right)+A Y \times\left(R I E_{K} \times H I_{K} \times 100 \%+R I E_{K} \times\left(1-H I_{K}\right) \times X_{S} \%\right) \times\right. \\
1.205\end{array}$ & Maize \\
\hline $\begin{array}{c}\text { (Colaço \& Molin, } \\
\text { 2017) }\end{array}$ & $K_{2} O_{i}=2.8591 \times$ Yield $\exp _{i}-49.2072 \times K_{\text {soili }}+91.7240$ & Orange \\
\hline (Wong et al., 2001) & $K_{2} O=0.95-2.6 \exp ^{-0.095 K_{0}}$ & $\begin{array}{l}\text { Multiple } \\
\text { crops }\end{array}$ \\
\hline (Rehm et al., 2006) & $K_{2} O=\left[0.166-0.0073 \times K_{\text {soil }}(\mathrm{ppm}) \mathrm{K}\right] \times \mathrm{EY}$ & Maize \\
\hline (Csathó et al., 2009) & $K_{2} O=\left(\mathrm{Y} \times \mathrm{SNR}_{Y} \times \mathrm{F}_{S N S}\right)+C$ & $\begin{array}{l}\text { Multiple } \\
\text { crops }\end{array}$ \\
\hline (Buresh et al., 2010) & $K_{2} O=\left(G Y-G Y_{0 K}\right) \times \frac{R I E_{K}}{R E_{K}}$ & Rice \\
\hline
\end{tabular}

$\mathrm{K}_{2} \mathrm{O}-\mathrm{K}$ requirement $\left(\mathrm{kg} \mathrm{ha}^{-1}\right) ; \mathrm{K}_{\text {soil }}$ - soil $\mathrm{K}$ content in parts per million; $\mathrm{YRK}_{\mathrm{K}}$ - yield response to fertilizer $\mathrm{K}\left(\mathrm{kg}\right.$ ha $\left.{ }^{-1}\right)$; RIEK $-\mathrm{reciprocal}$ internal efficiency, which is the nutrient absorption requirement per ton of grain yield $\left(\mathrm{kg} \mathrm{t}^{-1}\right)$; REK - recovery efficiency for $\mathrm{K}$ fertilizer application (\%); AY - attainable yield $\left(\mathrm{kg} \mathrm{ha}^{-1}\right)$; RIP - harvest index for P; RIEK - nutrient absorption requirement per ton of grain yield (kg $\left.\mathrm{t}^{-1}\right) ; \mathrm{HI}_{\mathrm{K}}$ - harvest index for $\mathrm{K} ; \mathrm{X}_{\mathrm{S}} \%$ - straw return ratio; 1,205 - conversion constant for $\mathrm{K} ; \mathrm{K}_{2} \mathrm{O}_{\mathrm{i}}-\mathrm{K}_{2} \mathrm{O}$ rate at pixel i $\left(\mathrm{kg} \mathrm{ha}^{-1}\right.$ ); Yield_expi - expected yield at pixel i $\left(\mathrm{t} \mathrm{ha}^{-1}\right)$; K_soili - soil $\mathrm{K}$ content at pixel i $\left(\mathrm{mmol}_{\mathrm{c}} \mathrm{dm}^{-3}\right)$; $\mathrm{K}_{0}$ - soil $\mathrm{K}$ using the Colwell test; SNRY specific nutrient requirements to achieve expected yield; FSNS - factor dependent on the amount of nutrient in the soil; $\mathrm{C}-$ correction factor; $\mathrm{GY}$ - grain yield $\left(\mathrm{t} \mathrm{ha}^{-1}\right)$; GYOK - grain yield $\left(\mathrm{t} \mathrm{ha}^{-1}\right)$ in the omission plot (where the required nutrient amount was not applied); RIEK - nutrient recovery efficiency $\left(\mathrm{kg} \mathrm{kg}^{-1}\right)$, determined with QUEFTS (quantitative evaluation of the fertility of tropical soils); REK - efficiency recovery.

\section{Software for recommending fertilizers with a focus on precision agriculture}

We sought to identify, throughout the SLS process, which cited software had the functionality to carry out fertilizer recommendation at varying rates (Table 10):

1) Nutrient Expert (NE) system: Decision support tool for fertilizer recommendation based on (i) characteristics of the growing environment, such as water availability (e.g., irrigated, totally rainy, and supplementary rain) and occurrences of flood or drought; (ii) soil fertility indicators (e.g., soil color and texture, and organic matter content), soil test for $\mathrm{P}$ or $\mathrm{K}$ (if any), historical use of organic materials (if any), and problematic soils (if any); (iii) cutting sequence in the farmer's cutting pattern; (iv) crop residues, inputs, and fertilizers management; and (v) farmers' current income. The system advocates site-specific nutrient management using the $4 \mathrm{R}$ nutrient management technique: (i) applying the right nutrient source, (ii) at the right rate, (iii) right time, and (iv) right place (VollmerSanders et al., 2016; Xu et al., 2017). This system can provide a recommendation of specific nutrients for small farmers who do not have access to soil tests. Therefore, it was designed to work with or without soil testing. The NE system estimates yield based on crop conditions, determines the nutrient balance in the crop system based on crop yield and the fertilizer applied to the previous crop, and combines this information with soil characteristics to generate a specific nutrient recommendation for the location (Sapkota et al., 2014).

2) RISSAC-RIA: Computerized recommendation system designed to help farmers rationally and economically use the available nutritional resources. The system includes fertilizer recommendations for 48 main crops, developed by experts from two academic institutes, the Research Institute for Soil Science and Agricultural Chemistry (RISSAC) in Budapest and the Agricultural Research Institute in Martonvásár, Hungary.

TABLE 10. Software for recommending fertilizers.

\begin{tabular}{lc}
\hline \multicolumn{1}{c}{ Software } & Developer \\
\hline Nutrient Expert & (Pampolino et al., 2012) \\
RISSAC-RIA & (Csathó et al., 2009) \\
Nutrient Manager for Rice & (IRRI, 2010) \\
SST Summit & (Aytasheva et al., 2014) \\
QUEFTS & (Janssen et al.,1990) \\
\hline
\end{tabular}

3) Nutrient Manager for Rice: Tool for decision making that consists of questions, which, according to the authors, can be answered within 15 minutes, without the need for soil analysis. The answers to the questions provide sufficient information to develop $\mathrm{K}$ and $\mathrm{P}$ recommendations for specific field fertilizers, using the approaches and algorithms described by Buresh et al. (2010).

4) SST Summit: System developed by the company SST Software, which produces other agricultural management systems with different purposes. The SST Summit allows working with soil fertility data to generate nutrient availability maps and fertilizer recommendation maps for application at varying rates. Also, it enables the creation of sowing maps at a varying rate (SST, 2019). 
5) QUEFTS: Software that implements a model to analyze the effect of nitrogen, phosphorus, and potassium limitation on crops grown in tropical soils. This system uses a methodology of successive calculations of potential nutrient supply, actual nutrient uptake, yield ranges, and yield ranges combined in pairs, in addition to an estimate of production. The process is carried out in four successive stages: (i) calculation of the potential supply of N, P, and K; (ii) calculation of the actual expected absorption of each nutrient as a function of its potential supply, considering the potential supply of the other two nutrients; (iii) establishment of three yield ranges depending on the actual absorptions of N, P, and K; and (iv) association of these income ranges in pairs by calculating the final estimate of yield (Janssen et al., 1990).

The US university extension services commonly provide nutrient recommendation worksheets, some of them using recommendation ranges, such as Shapiro et al. (2008), and others employ recommendation models, such as Rehm et al. (2006).

\section{CONCLUSIONS}

The use of the systematic literature study (SLS), consisting of the steps of systematic literature mapping (SLM), snowballing (SB), and systematic literature review (SLR), was an effective tool for researchers to identify relevant studies for their research and deepen in the researched subject. The methodology used by SLM to reduce the volume of studies from reading titles and abstracts results in a significant reduction in the volume of final studies to be used for SLR, focusing only on studies of greater importance for the subject in question. In turn, SB assists in identifying relevant studies that did not appear in the primary search (SLM).

The survey carried out through SLM obtained 366 scientific papers, which were reduced to 20 papers after a selection process. In addition, another 26 studies selected by snowballing (FSB and BSB) were added to them, resulting in 46 articles used in this study.

The identified fertilizer recommendation methods resulted from studies published in several countries, demonstrating the different approaches used in the treatment of crop nutritional demands. Twelve $\mathrm{N}$ recommendation methods were identified after analyzing the studies, eight of which were recommended for $\mathrm{P}$ and seven of K. Only five precision agriculture software that had the functionality to carry out fertilizer recommendations at varying rates were found in the analyzed articles.

\section{ACKNOWLEDGMENTS}

The authors are grateful to the Western Paraná State University (UNIOESTE), the Federal Technological University of Paraná (UTFPR), the Araucária Foundation (Fundação Araucária), the Coordination for the Improvement of Higher Education Personnel (CAPES), the National Council for Scientific and Technological Development $(\mathrm{CNPq})$, and the Itaipu Technological Park Foundation (FPTI), for the support received.

\section{REFERENCES}

Adams ML, Cook S, Bowden JW (2000) Using yield maps and intensive soil sampling to improve nitrogen fertiliser recommendations from a deterministic model in the Western Australian wheatbelt. Australian Journal of Experimental Agriculture 40(7):959. DOI: https://doi.org/10.1071/EA99129

Amaral LR do, Molin JP (2011) Sensor óptico no auxílio à recomendação de adubação nitrogenada em cana-deaçúcar. Pesquisa Agropecuária Brasileira 46(12):16331642. DOI: https://doi.org/10.1590/S0100204X2011001200008

Arregui LM, Lasa B, Lafarga A, Irañeta I, Baroja E, Quemada M (2006) Evaluation of chlorophyll meters as tools for $\mathrm{N}$ fertilization in winter wheat under humid Mediterranean conditions. European Journal of Agronomy 24(2):140-148. DOI:

https://doi.org/10.1016/j.eja.2005.05.005

Atherton BC, Morgan MT, Shearer SA, Stombaugh TS, Ward AD (1999) Site-specific farming: A perspective on information needs, benefits and limitations. Journal of Soil and Water Conservation 54(2):455 LP - 461. Available: http://www.jswconline.org/content/54/2/455.abstract

Ayoubi S, Mohammad Zamani S, Khormali F (2012) Spatial variability of some soil properties for site specific farming in northern Iran. International Journal of Plant Production 1(2):225-236. DOI: https://doi.org/10.22069/ijpp.2012.539

Aytasheva ZG, Polischyuk E V, Bykova CS, Baiseyitova SK, Polimbetova FA (2014) Computational planting management in developing bean and pumpkin collections. International Journal of Biology and Chemistry 7(1):3-8.

Basso B, Bertocco M, Sartori L, Martin EC (2007) Analyzing the effects of climate variability on spatial pattern of yield in a maize-wheat-soybean rotation. European Journal of Agronomy 26(2):82-91. DOI: https://doi.org/10.1016/j.eja.2006.08.008

Beckie HJ, Moulin AP, Pennock DJ (1997) Strategies for variable rate nitrogen fertilization in hummocky terrain. Canadian Journal of Soil Science 77(4):589-595. DOI: https://doi.org/10.4141/S96-095

Birrell SJ, Sudduth KA, Kitchen NR (1996) Nutrient mapping implications of short-range variability. Proceedings of the Third International Conference on Precision Agriculture 207-216.

Blackmer AM, (1997) Nitrogen fertilizer recommendations for corn in Iowa.

Bray RH, Kurtz LT (1945) Determination of total, organic, and available forms of phosphorus in soils. Soil Science 59(1):39-46. DOI: https://doi.org/10.1097/00010694194501000-00006

Bullock DS, Lowenberg-DeBoer J (2007) Using spatial analysis to study the values of variable rate technology and information. Journal of Agricultural Economics 58(3):517535. DOI: https://doi.org/10.22004/ag.econ.25393 
Buresh RJ, Pampolino MF, Witt C (2010) Field-specific potassium and phosphorus balances and fertilizer requirements for irrigated rice-based cropping systems. Plant and Soil 335(1-2):35-64. DOI:

https://doi.org/10.1007/s11104-010-0441-z

Chen W, Bell RW, Brennan RF, Bowden JW, Dobermann A, Rengel Z, Porter W (2009) Key crop nutrient management issues in the Western Australia grains industry: a review. Soil Research 47(1):1. DOI: https://doi.org/10.1071/SR08097

Coelho AM, Franca GE de, Bahia Filho AFC, Guedes GAA, (1992) Doses e métodos de aplicação de fertilizantes nitrogenados na cultura do milho sob irrigação. Revista Brasileira de Ciência do Solo 16: 61-67.

Cohen N, Arieli T (2011) Field research in conflict environments: Methodological challenges and snowball sampling. Journal of Peace Research 48(4):423-435. DOI: https://doi.org/10.1177/0022343311405698

Colaço AF, Molin JP (2017) Variable rate fertilization in citrus: a long term study. Precision Agriculture 18(2):169191. DOI: https://doi.org/10.1007/s11119-016-9454-9

Csathó P, Árendás T, Fodor N, Németh T (2009) Evaluation of Different Fertilizer Recommendation Systems on Various Soils and Crops in Hungary. Communications in Soil Science and Plant Analysis 40(11-12):1689-1711. DOI:

https://doi.org/10.1080/00103620902895797

Devkota KP, McDonald AJ, Khadka L, Khadka A, Paudel G, Devkota M (2016) Fertilizers, hybrids, and the sustainable intensification of maize systems in the rainfed mid-hills of Nepal. European Journal of Agronomy 80 154-167. DOI: https://doi.org/10.1016/j.eja.2016.08.003

Dinnes DL, Karlen DL, Jaynes DB, Kaspar TC, Hatfield JL, Colvin TS, Cambardella CA (2002) Nitrogen Management Strategies to Reduce Nitrate Leaching in Tile-Drained Midwestern Soils. Agronomy Journal 94(1):153. DOI: https://doi.org/10.2134/agronj2002.1530

Dobermann A, Cassman KG (2002) Plant nutrient management for enhanced productivity in intensive grain production systems of the United States and Asia. Plant and Soil 247(1):153-175. DOI:

https://doi.org/10.1023/A:1021197525875

Duchesne L, Moore J-D, Ouimet R (2013) Partitioning the Effect of Release and Liming on Growth of Sugar Maple and American Beech Saplings. Northern Journal of Applied Forestry 30(1): 28-36. DOI:

https://doi.org/10.5849/njaf.12-012

Elprince AM (2009) Prediction Soil Fertilization Maps Using Logistic Modeling and a Geographical Information System. Soil Science Society of America Journal 73(6): 2032-2042. DOI: https://doi.org/10.2136/sssaj2008.0369

Febrero F, Calero C, Moraga MÁ (2014) A Systematic Mapping Study of Software Reliability Modeling. Information and Software Technology 56(8): 839-849. DOI: https://doi.org/10.1016/j.infsof.2014.03.006
Francis DD, Schepers JS, Vigil MF (1993) Post-Anthesis Nitrogen Loss from Corn. Agronomy Journal 85(3): 659663. DOI:

https://doi.org/10.2134/agronj1993.00021962008500030026x

Frogbrook ZL, Oliver MA, Salahi M, Ellis RH (2006) Exploring the spatial relations between cereal yield and soil chemical properties and the implications for sampling. Soil Use and Management 18(1): 1-9. DOI: https://doi.org/10.1111/j.1475-2743.2002.tb00043.x

Goulding KWT (2016) Soil acidification and the importance of liming agricultural soils with particular reference to the United Kingdom. Soil Use and Management 32(3): 390-399. DOI: https://doi.org/10.1111/sum. 12270

Haneklaus S, Schnug E (2000) Decision-making strategies for the variable-rate application of compound fertilizers. Communications in Soil Science and Plant Analysis 31(11-14): 1863-1873. DOI: https://doi.org/10.1080/00103620009370543

Hinsinger P (2001) Bioavailability of soil inorganic P in the rhizosphere as affected by root-induced chemical changes: a review. Plant and Soil 237(2): 173-195. DOI: https://doi.org/10.1023/A:1013351617532

Hoeft RG, Peck TR (1998) Illinois Agronomy Handbook. Illinois, University of Illinois at Urbana-Champaign, College of Agricultural.

IRRI (2010) Nutrient management decision tools. (p. 190)

ISPA (2019) Definition of precision agriculture. Available: https://www.ispag.org/

Jalali S, Wohlin C (2012) Systematic literature studies. Proceedings of the ACM-IEEE International Symposium on Empirical Software Engineering and Measurement ESEM '12 29. DOI:

https://doi.org/10.1145/2372251.2372257

Janssen BH, Guiking FCT, van der Eijk D, Smaling EMA, Wolf J, van Reuler H (1990) A system for quantitative evaluation of the fertility of tropical soils (QUEFTS). Geoderma 46(4): 299-318. DOI: https://doi.org/10.1016/0016-7061(90)90021-Z

Jin J, Jiang C (2002) Spatial variability of soil nutrients and site-specific nutrient management in the P.R. China. Computers and Electronics in Agriculture 36(2-3):165172. DOI: https://doi.org/10.1016/S0168-1699(02)00099-6

Johnston AE, Poulton PR, Fixen PE, Curtin D (2014) Phosphorus: (177-228) DOI: https://doi.org/10.1016/B978-0-12-420225-2.00005-4

Kahabka JE, Van Es HM, McClenahan EJ, Cox WJ (2004) Spatial Analysis of Maize Response to Nitrogen Fertilizer in Central New York. Precision Agriculture 5(5): 463-476. DOI: https://doi.org/10.1007/s11119-004-5320-2

Keele S (2007) Guidelines for performing systematic literature reviews in software engineering Durham, University of Durham. 57p. 
Kersebaum KC, Lorenz K, Reuter HI, Schwarz J, Wegehenkel M, Wendroth O (2005) Operational use of agro-meteorological data and GIS to derive site specific nitrogen fertilizer recommendations based on the simulation of soil and crop growth processes. Physics and Chemistry of the Earth, Parts A/B/C 30(1-3): 59-67. DOI: https://doi.org/10.1016/j.pce.2004.08.021

Khanna M, Isik M, Winter-Nelson A (2000) Investment in site-specific crop management under uncertainty: implications for nitrogen pollution control and environmental policy. Agricultural Economics 24(1): 9-12. DOI: https://doi.org/10.1111/j.1574-0862.2000.tb00089.x

Lambert DM, Lowenberg-DeBoer J, Malzer G (2007) Managing phosphorous soil dynamics over space and time. Agricultural Economics 37(1): 43-53. DOI: https://doi.org/10.1111/j.1574-0862.2007.00221.x

Liu Y, Swinton SM, Miller NR (2006) Is Site-Specific Yield Response Consistent over Time? Does It Pay? American Journal of Agricultural Economics 88(2): 471-483. DOI: https://doi.org/10.1111/j.1467-8276.2006.00872.x

Lowenberg-DeBoer J, Aghib A (1999) Average Returns and Risk Characteristics of Site Specific P and K Management: Eastern Corn Belt On-Farm Trial Results. Journal of Production Agriculture 12(2): 276-282. DOI: https://doi.org/10.2134/jpa1999.0276

Lv X, Chen Y (2009) Definition of Management Zones of Soil Nutrients Based on Spatial Analysis in Cotton Field. 2009 Sixth International Conference on Fuzzy Systems and Knowledge Discovery 506-510. DOI:

https://doi.org/10.1109/FSKD.2009.726

Ma B-L, Wu T-Y, Shang J (2014) On-farm comparison of variable rates of nitrogen with uniform application to maize on canopy reflectance, soil nitrate, and grain yield. Journal of Plant Nutrition and Soil Science 177(2): 216226. DOI: https://doi.org/10.1002/jpln.201200338

Ma BL, Wu TY, Tremblay N, Deen W, Morrison MJ, Mclaughlin NB, Gregorich EG, Stewart G (2010) Nitrous oxide fluxes from corn fields: on-farm assessment of the amount and timing of nitrogen fertilizer. Global Change Biology 16(1): 156-170. DOI:

https://doi.org/10.1111/j.1365-2486.2009.01932.x

Mahler RL (2008) Nutrients plants require for growth. University of Idaho College of Agricultural and Life Sciences.

Martha GB, Corsi M, Trivelin PCO, Alves MC (2004) Nitrogen recovery and loss in a fertilized elephant grass pasture. Grass and Forage Science 59(1): 80-90. DOI: https://doi.org/10.1111/j.1365-2494.2004.00407.x

Mehlich A (1953) Determination of P, Ca, Mg, K, Na, and NH4. North Carolina Soil Test Division, p23-89.

Mehlich A (1978) New extractant for soil test evaluation of phosphorus, potassium, magnesium, calcium, sodium, manganese and zinc. Communications in Soil Science and Plant Analysis 9(6): 477-492. DOI:

https://doi.org/10.1080/00103627809366824
Mehlich A (1984) Mehlich 3 soil test extractant: A modification of Mehlich 2 extractant. Communications in Soil Science and Plant Analysis 15(12): 1409-1416. DOI: https://doi.org/10.1080/00103628409367568

Meyer-Aurich A, Weersink A, Gandorfer M, Wagner P (2010) Optimal site-specific fertilization and harvesting strategies with respect to crop yield and quality response to nitrogen. Agricultural Systems 103(7): 478-485. DOI: https://doi.org/10.1016/j.agsy.2010.05.001

Miao Y, Mulla DJ, Robert PC (2018) An integrated approach to site-specific management zone delineation. Frontiers of Agricultural Science and Engineering. DOI: https://doi.org/10.15302/J-FASE-2018230

Molin JP, Motomiya AV de A, Frasson FR, Faulin GDC, Tosta W (2010) Test procedure for variable rate fertilizer on coffee. Acta Scientiarum. Agronomy 32(4):. DOI: https://doi.org/10.4025/actasciagron.v32i4.5282

Nogara Neto F, Roloff G, Dieckow J, Motta ACV (2011) Atributos de solo e cultura espacialmente distribuídos relacionados ao rendimento do milho. Revista Brasileira de Ciência Do Solo 35(3): 1025-1036. DOI: https://doi.org/10.1590/S0100-06832011000300036

Olfs H-W, Blankenau K, Brentrup F, Jasper J, Link A, Lammel J (2005) Soil- and plant-based nitrogen-fertilizer recommendations in arable farming. Journal of Plant Nutrition and Soil Science 168(4): 414-431. DOI: https://doi.org/10.1002/jpln.200520526

Olsen SR (1954) Estimation of available phosphorus in soils by extraction with sodium bicarbonate (Issue 939). US Department of Agriculture.

Omafra (2005) Food and rural affairs. In: Soil Fertility Handbook. Ontario, p190.

ONU (2021) World population prospects. Department of Economic and Social Affairs.

Pampolino MF, Witt C, Pasuquin JM, Johnston A, Fisher MJ (2012) Development approach and evaluation of the Nutrient Expert software for nutrient management in cereal crops. Computers and Electronics in Agriculture 88 103110. DOI: https://doi.org/10.1016/j.compag.2012.07.007

Petersen K, Vakkalanka S, Kuzniarz L (2015) Guidelines for conducting systematic mapping studies in software engineering: An update. Information and Software Technology 64:1-18. DOI:

https://doi.org/10.1016/j.infsof.2015.03.007

Pierce FJ, Nowak P (1999) Aspects of Precision Agriculture, p1-85. DOI: https://doi.org/10.1016/S00652113(08)60513-1

Rajsic P, Weersink A (2008) Do farmers waste fertilizer? A comparison of ex post optimal nitrogen rates and ex ante recommendations by model, site and year. Agricultural Systems 97(1-2): 56-67. DOI: https://doi.org/10.1016/j.agsy.2007.12.001

Raun WR, Johnson GV (1999) Improving Nitrogen Use Efficiency for Cereal Production. Agronomy Journal 91(3): 357-363. DOI:

https://doi.org/10.2134/agronj1999.00021962009100030001x 
Raun WR, Solie JB, Johnson G V., Stone ML, Mullen RW, Freeman KW, Thomason WE, Lukina E V (2002) Improving Nitrogen Use Efficiency in Cereal Grain Production with Optical Sensing and Variable Rate Application. Agronomy Journal 94(4): 815-820. DOI: https://doi.org/10.2134/agronj2002.8150

Rehm G, Randall G, Lamb J, Eliason R (2006) Fertilizing corn in Minnesota. FO-0379O. St Paul, University of Minnesota.

Rejesus RM, Hornbaker RH (1999) Economic and environmental evaluation of alternative pollution-reducing nitrogen management practices in central Illinois. Agriculture, Ecosystems \& Environment 75(1-2): 41-53. DOI: https://doi.org/10.1016/S0167-8809(99)00058-4

Robert PC (2002) Precision agriculture: a challenge for crop nutrition management. Plant and Soil 247(1): 143149. DOI: https://doi.org/10.1023/A:1021171514148

Robertson MJ, Llewellyn RS, Mandel R, Lawes R, Bramley RG V, Swift L, Metz N, O'Callaghan C (2012) Adoption of variable rate fertiliser application in the Australian grains industry: status, issues and prospects. Precision Agriculture 13(2): 181-199. DOI: https://doi.org/10.1007/s11119-011-9236-3

Sapkota TB, Majumdar K, Jat ML, Kumar A, Bishnoi DK, McDonald AJ, Pampolino M (2014) Precision nutrient management in conservation agriculture based wheat production of Northwest India: Profitability, nutrient use efficiency and environmental footprint. Field Crops Research 155 233-244. DOI:

https://doi.org/10.1016/j.fcr.2013.09.001

Schirrmann M, Domsch H (2011) Sampling procedure simulating on-the-go sensing for soil nutrients. Journal of Plant Nutrition and Soil Science 174(2): 333-343. DOI: https://doi.org/10.1002/jpln.200900367

Schnug E, Panten K, Haneklaus S (1998) Sampling and nutrient recommendations - the future. Communications in Soil Science and Plant Analysis 29(11-14): 1455-1462. DOI: https://doi.org/10.1080/00103629809370042

Shanahan JF, Kitchen NR, Raun WR, Schepers JS (2008) Responsive in-season nitrogen management for cereals. Computers and Electronics in Agriculture 61(1): 51-62. DOI: https://doi.org/10.1016/j.compag.2007.06.006

Shapiro CA, Ferguson RB, Hergert GW, Dobermann A, Wortmann CS (2008) Fertilizer suggestions for corn. University of Nebraska-Lincoln, Extension.

Shukla AK, Sinha NK, Tiwari PK, Prakash C, Behera SK, Lenka NK, Singh VK, Dwivedi BS, Majumdar K, Kumar A, Srivastava PC, Pachauri SP, Meena MC, Lakaria BL, Siddiqui S (2017) Spatial Distribution and Management Zones for Sulphur and Micronutrients in Shiwalik Himalayan Region of India. Land Degradation \& Development 28(3): 959-969. DOI:

https://doi.org/10.1002/ldr.2673

Silva FC da, Raij B Van (1999) Disponibilidade de fósforo em solos avaliada por diferentes extratores. Pesquisa Agropecuária Brasileira 34(2): 267-288. DOI: https://doi.org/10.1590/S0100-204X1999000200016
SST (2019) Summit professional. Available:

http://www.sstsoftware.com.br/agricultura-de-precisaoSST-summit.html

Stanger TF, Lauer JG (2008) Corn Grain Yield Response to Crop Rotation and Nitrogen over 35 Years. Agronomy Journal 100(3): 643-650. DOI:

https://doi.org/10.2134/agronj2007.0280

Stępień M, Gozdowski D, Samborski S (2013) A case study on the estimation accuracy of soil properties and fertilizer rates for different soil-sampling grids. Journal of Plant Nutrition and Soil Science 176(1): 57-68. DOI: https://doi.org/10.1002/jpln.201100422

Talavera JM, Tobón LE, Gómez JA, Culman MA, Aranda JM, Parra DT, Quiroz LA, Hoyos A, Garreta LE (2017)

Review of IoT applications in agro-industrial and environmental fields. Computers and Electronics in Agriculture 142 283-297. DOI:

https://doi.org/10.1016/j.compag.2017.09.015

Tola E, Kataoka T, Burce M, Okamoto H, Hata S (2008) Granular fertiliser application rate control system with integrated output volume measurement. Biosystems Engineering 101(4): 411-416. DOI:

https://doi.org/10.1016/j.biosystemseng.2008.09.019

van Es HM, Yang CL, Geohring LD (2005) Maize Nitrogen Response as Affected by Soil Type and Drainage Variability. Precision Agriculture 6(3): 281-295. DOI: https://doi.org/10.1007/s11119-005-1387-7

van Raij B, (1983) Avaliação da fertilidade do solo. Piracicaba, Instituto Internacional da Potassa.

van Raij B, Cantarella H, Quaggio JA (2002) Rationale of the economy of soil testing. Communications in Soil Science and Plant Analysis 33(15-18):2521-2536. DOI: https://doi.org/10.1081/CSS-120014463

Verhagen A, Booltink HW, Bouma J (1995) Site-specific management: balancing production and environmental requirements at farm level. Agricultural Systems 49(4): 369-384.

Verhagen J (1997) Site specific fertiliser application for potato production and effects on N-leaching using dynamic simulation modelling. Agriculture, Ecosystems \& Environment 66(2): 165-175. DOI:

https://doi.org/10.1016/S0167-8809(97)00086-8

Vollmer-Sanders C, Allman A, Busdeker D, Moody LB, Stanley WG (2016) Building partnerships to scale up conservation: 4R Nutrient Stewardship Certification Program in the Lake Erie watershed. Journal of Great Lakes Research 42(6): 1395-1402. DOI: https://doi.org/10.1016/j.jglr.2016.09.004

Waring RH, Schlesinger WH (1985) Forest ecosystems. Analysis at Multiples Scales 55. Academic Press. 340p.

Wohlin C (2014) Guidelines for snowballing in systematic literature studies and a replication in software engineering. Proceedings of the 18th International Conference on Evaluation and Assessment in Software Engineering EASE' 14 1-10. DOI:

https://doi.org/10.1145/2601248.2601268 
Wong MTF, Corner RJ, Cook SE (2001) A decision support system for mapping the site-specific potassium requirement of wheat in the field. Australian Journal of Experimental Agriculture 41(5):655. DOI:

https://doi.org/10.1071/EA00191

Wong MTF, Edwards NK, Barrow NJ (2000) Accessibility of subsoil potassium to wheat grown on duplex soils in the south-west of Western Australia. Soil Research 38(3): 745. DOI: https://doi.org/10.1071/SR98117

Wood M, Litterick AM (2017) Soil health - What should the doctor order? Soil Use and Management 33(2): 339345. DOI: https://doi.org/10.1111/sum.12344

Xu X, He P, Qiu S, Pampolino MF, Zhao S, Johnston AM, Zhou W (2014) Estimating a new approach of fertilizer recommendation across small-holder farms in China. Field Crops Research 163 10-17. DOI:

https://doi.org/10.1016/j.fcr.2014.04.014
Xu X, He P, Zhang J, Pampolino MF, Johnston AM, Zhou W (2017) Spatial variation of attainable yield and fertilizer requirements for maize at the regional scale in China. Field Crops Research 203 8-15. DOI: https://doi.org/10.1016/j.fcr.2016.11.013

Zhang N, Wang M, Wang N (2002) Precision agriculture - a worldwide overview. Computers and Electronics in Agriculture 36(2-3):113-132. DOI: https://doi.org/10.1016/S0168-1699(02)00096-0

Ziadi N, Bélanger G, Claessens A (2012) Relationship between soil nitrate accumulation and in-season corn $\mathrm{N}$ nutrition indicators. Canadian Journal of Plant Science 92(2):331-339. DOI: https://doi.org/10.4141/cjps2011-086

Ziadi N, Cambouris AN, Nyiraneza J, Nolin MC (2013) Across a landscape, soil texture controls the optimum rate of $\mathrm{N}$ fertilizer for maize production. Field Crops Research 148 78-85. DOI: https://doi.org/10.1016/j.fcr.2013.03.023 